\title{
Statyba
}

\section{SUBSTANTIATION OF NEW STANDARD METHODS FOR DEFINITION OF OPERATIONAL FROST RESISTANCE OF FACING PROTECTIONS AND CONCRETE}

\section{R. Mačiulaitis \& D. Žemaitytè}

To cite this article: $R$. Mačiulaitis \& D. Žemaitytè (1998) SUBSTANTIATION OF NEW STANDARD METHODS FOR DEFINITION OF OPERATIONAL FROST RESISTANCE OF FACING

PROTECTIONS AND CONCRETE, Statyba, 4:3, 227-234, DOI: $10.1080 / 13921525.1998 .10531409$

To link to this article: https://doi.org/10.1080/13921525.1998.10531409

曲 Published online: 26 Jul 2012.

Submit your article to this journal $[\pi$

山 Article views: 46 


\title{
SUBSTANTIATION OF NEW STANDARD METHODS FOR DEFINITION OF OPERATIONAL FROST RESISTANCE OF FACING PROTECTIONS AND CONCRETE
}

\author{
R. Mačiulaitis, D. Žemaitytė
}

\section{Introduction}

It is well-known that durability of stone and reinforced stone walls (structures) potentially depends on durability and deformation, on the parameters of frost resistance of their component materials and products. On the other hand, the changes of these parameters during a service of structures are predetermined by the influence of the main climatic factors and features of relief, building density of district, etc.

If initially a certain grade of construction materials and products with a definite durability is not a subject of sharp discussion in the aspect of projected or actual durability of designs, it could not be told the same about their grade of frost resistance. For example, now in Lithuania $\mathrm{CH}$ and $\Pi$ II-22 are in force (in building norms and regulations) and it is indicated there that application in the above-mentioned structures of products, with the grade of frost resistance that equals F50, will provide durability for walls of premises for about 100 years (even with adverse microclimate in them). However, there is no correspondence to the facts of prolonged research [1 - 3] on ceramic brick and stone masonry or other materials. Besides, the range of the grades of frost resistance in these specifications vary for different but functionally monotonous products or materials. It is necessary to note that for concrete or concrete products this range is much wider than for ceramic or sand-lime brick and stone. The similar tendency is traced in the appropriate standards for such functionally monotonous products if there were certain requirements to their frost resistance. Probably that even while working out the above-mentioned $\mathrm{CH}$ and $\Pi$, the definition of interrelation between a parameter of structural durability and frost resistance of the component products and materials was based on the results obtained for their grade according to frost resistance; the grade was ascertained by tests based on the classical principle of volumetric freezing. Earlier this principle dominated in all standard techniques for defining frost resistance of various products. It is possible to assume that the final data for durability prediction according to this parameter was erroneous.

\section{The point of the matter}

The main point is that in time structures, products and materials undergo obviously directed, unilateral (one side) freezing, if the enclosure walls or structures are in an appropriate climatic zone. The question here can arise only about the influence of the volume factor and size of enclosure walls. The complex research of facing and ordinary ceramic brick and stone for simple or reinforced masonry in 1978 led to a new method of definition of frost resistance with unilateral freezing in the former Soviet Union. This technique was already recognized as basic for obverse ceramic products and in $\mathbf{1 9 8 0}$ for an ordinary ceramic brick and stone as well. After fundamental long researches its advanced methodical version and new test equipment were subjected to repeated careful analysis of the experts in 1989-1991. At last these developments were approved and even distributed for application to sand-lime brick and stone. In 1991-1992 the new method was included in the appropriate standards of independent Lithuania for estimation of this parameter of the above-mentioned products [1].

However, in 1978 and later no particular steps were taken to specify interrelation between the dura- 
bility of such products in structures and their grade of frost resistance under natural conditions and to present suggestions for changes in the above-mentioned $\mathrm{CH}$ and $\Pi$ or other specifications.

The solution of the problem inevitably requires the explanation of basic reasons that caused it. In our point of view, there are many reasons, but it is necessary to emphasize the main.

First, the classification of building materials and products is generally based on their nature or chemical structure. Only then the attention is paid to their mechanical, physical and other properties and the area of application. In this general context frost resistance as a physical property of materials and products is insufficiently theoretically reasonable, as well as the standard methods of its definition refer to a classical principle of volumetric freezing.

Second, the actual (service, operational) frost resistance of walls, facing materials and products strongly differs, that is really reflected in the now working standards. It is clear while comparing ceramic products to the concrete ones though their application in structures or enclosure walls is functionally identical.

Third, the designers and architects obviously insufficiently know and apply the products of a higher grade (for example, the grade of ceramic or sand-lime brick) on actual frost resistance, that is stipulated in the latest working standards. It's natural that it is necessary to define the grade of products in working standard techniques based on the principle of unilateral freezing. In this case it is very important to answer the question whether this principle is valid. We think it is necessary to answer this question affirmatively.

\section{Purpose of the work}

The aim of the work was the substantiation of two new standards that allow to determine the actual frost resistance of facing composites and products or samples of any sort of concrete, because the question of a durability depending on this parameter under natural conditions is urgent.

\section{Basic methodical principles}

Inspection of various buildings, structures and their fragments, masonry under natural conditions was being carried out periodically within several decades. Thus the condition of structures and especially their surface was estimated visually. In order to perform comparative laboratory research we applied identical samples. The frost resistance of samples or products was determined using classical volumetric freezing principle and unilateral freezing principle as well and applying standardization technique tests $[1,4]$. Experimental data processing was carried out by the known methods of mathematical statistics [5].

\section{Categories of the product service conditions and grade of actual frost resistance that ensures sufficient durability of designs}

When solving this important question we observed the requirements of the projects EN, LST 1457:1997 and LST 1330:1995. Distinction in the rules on operational conditions presented in these documents consists in various quantity of categories and also in qualitative characteristics. So walls and facing products are divided into three categories according to service conditions. For concrete there are more categories. It is obvious that these conditions predetermine durability. From our point of view it is enough to have three categories in the meanwhile. Thus it was necessary to establish the particular grade of operational frost resistance for specific products of each category.

Nobody has carried out similar tests for ceramic designs under natural conditions in Lithuania and even in other countries. Therefore it was necessary to refer to our own results of research [6 - 9]. The last of three basic techniques for defining frost resistance, that is based on unilateral freezing, judging by the results of mathematical data (obtained under laboratory and natural conditions) have appeared to be precise, reliable and accelerated. Thus it is necessary to emphasize that the results of tests performed with identical samples according to all those techniques are different. However, their correlation is very strong. Thus the grade (as a number) of service frost resistance is predetermined by a particular basic method, on the one hand, and by the products, on the other [ 6 - 9].

According to the results of our research $[1,6]$ ceramic and sand-lime facade products undergo the most severe destruction, various sorts of facing mate- 
rials - less intensive, concrete and reinforced concrete undergo the least destruction. The durability question of operational frost resistance of enclosure walls made of a various composites is very important. Structures of concrete and reinforced concrete, as our examinations show, also collapse sometimes rather quickly. Especially it concerns those objects that undergo the most aggressive influence of the climatic and service factors. After all, the question of durability during service frost resistance of new renovation products or materials is the most urgent, the standards of Lithuania are not developed yet for them. In general any facing collapse occurs identically to facade ceramics. Hence it is possible to rely completely on prolonged research of face ceramic brick that was carried out by us [6-8].

Besides, the necessity of application of new standard methods including the appropriate classification in categories and grades is illustrated by the data in Fig 1-8. They require some brief commentaries. It is obvious that all the presented structures undergo a unidirectional freezing and collapse basically from a surface by exfoliation with a growth of destruction depth, irrespective of temperature gradient. Also, the character of destruction does not depend on various natural climatic conditions and different components of protecting structures.

The shown characteristic destructions of objects were fixed already after $10-25$ years in service under natural conditions. The above-stated data coincide with the results of our research on the durability of operational frost resistance of ceramic masonry. On the other hand, the data (Fig 1-8) confirm the necessity of gradation service conditions for materials and products in various structures, which durability in respect of operational frost resistance must be probably 50 - 70 years. Here then it wouldn't be necessary to solve such problems.

\section{Comparative test for frost resistance of structural concrete samples with various ways of freezing}

Though the necessity for application of technique based on the principle of unilateral freezing is obvious, it does not mean its realization at the level of standards. It was already specified that the proofs of necessity of its application are reasonable in respect of fundamental research of facade ceramics and episodic - of sand-lime products and layered composites as well. In the latter case few tests were performed and we used a rather small amount of samples. The conclusive results confirmed analogy with facade ceramics. However, our opponents expected some exceptions in case of comparative frost resistance research of samples of heavy structural concrete. In this context such research works are of great interest. Therefore we realized two series of tests with different concrete samples. In the first series of research tests up to 100 cycles were ordered.

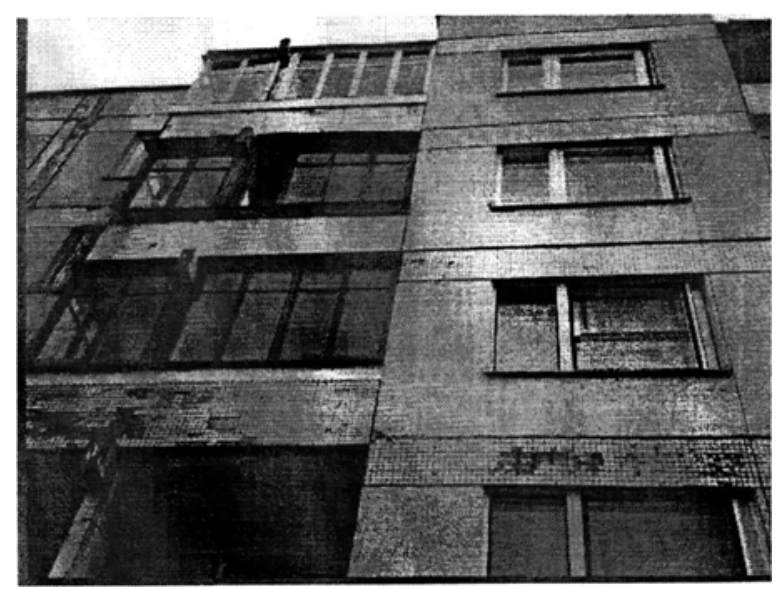

Fig 1. Destruction by exfoliation of decorative facing carpet of enameled ceramic tile of house facade in Ukmerges St 55 alter 20 years of service under natural conditions

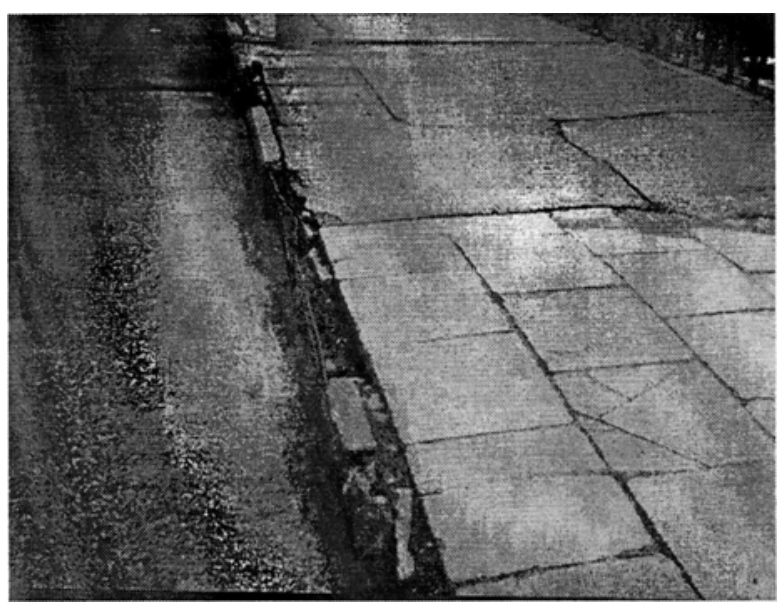

Fig 2. Destruction of reinforced borders of the bridge Valakampiai across the River Neris after 25 years of service 


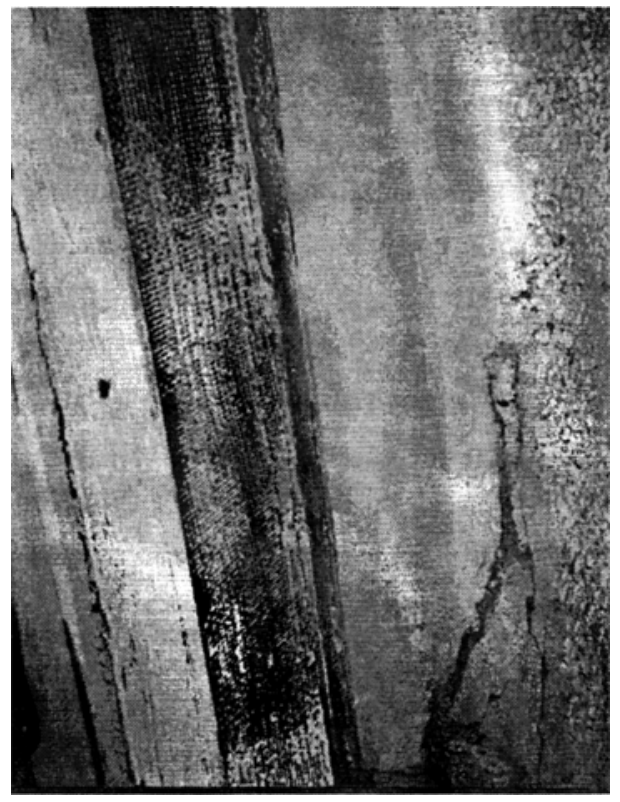

Fig 3. Destruction by exfoliation of panel house (9 floor) surface fragment in Šškinè St 73 after 18 years of service

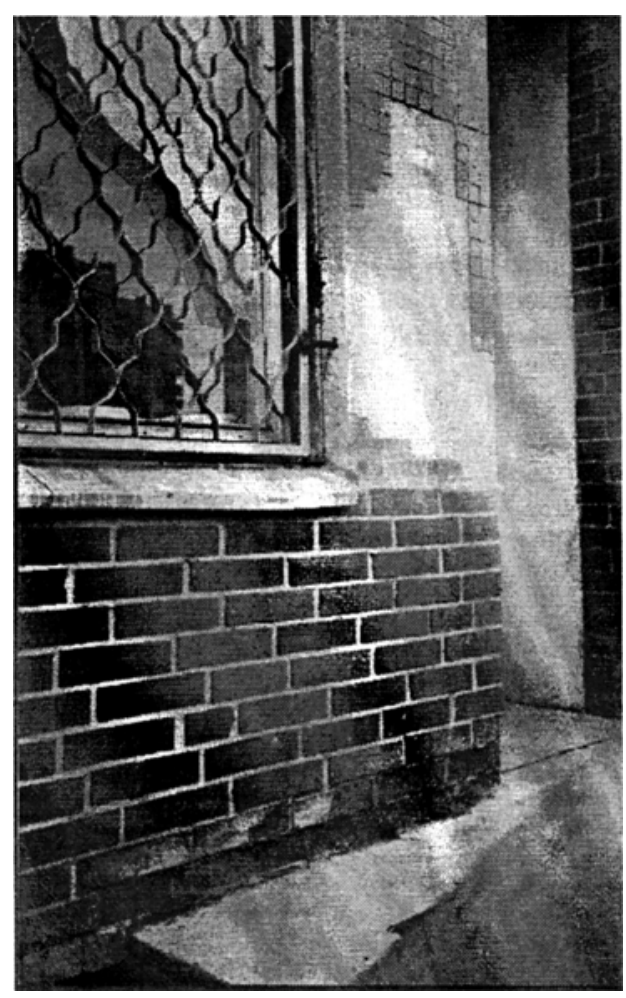

Fig 4. Destruction by exfoliation of polyclinic facade decorative facing out of carpet usual ceramic tiles in microarea Šeškinè after 10 years of service

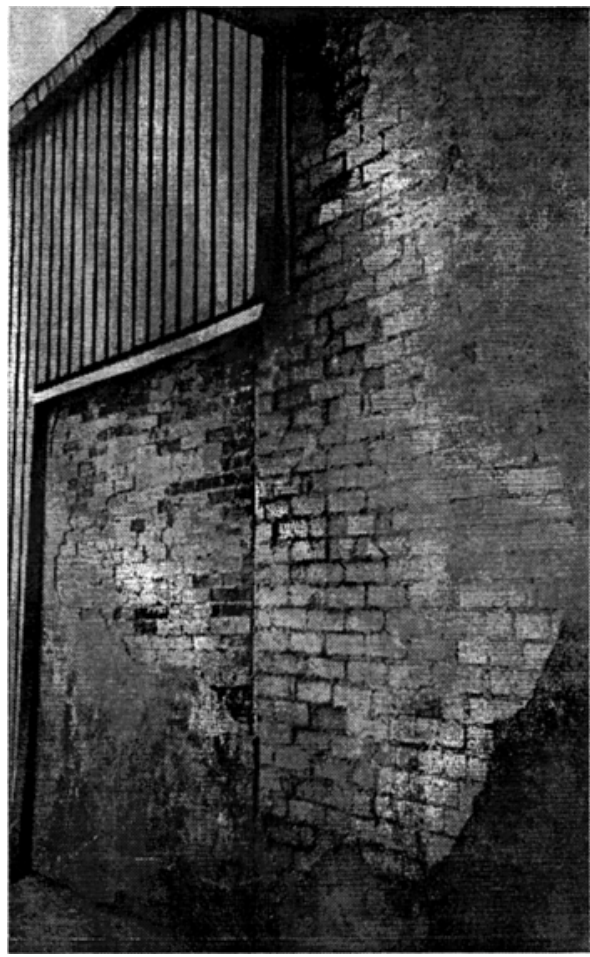

Fig 5. Destruction by exfoliation of usual plaster on ceramic and sand-lime brick masonry facade of the industrial building of institute Termoizoliacija in Linkmenų St 28 after 10 years of service

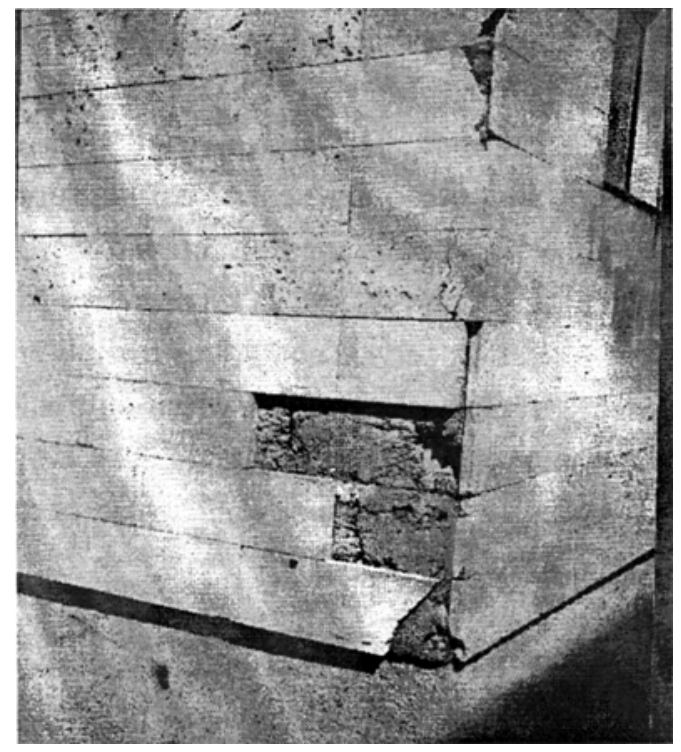

Fig 6. Destruction by exfoliation of decorative tiles in dolomite facade of VGTU building in Sauletekio al. 11 after 20 years of service 


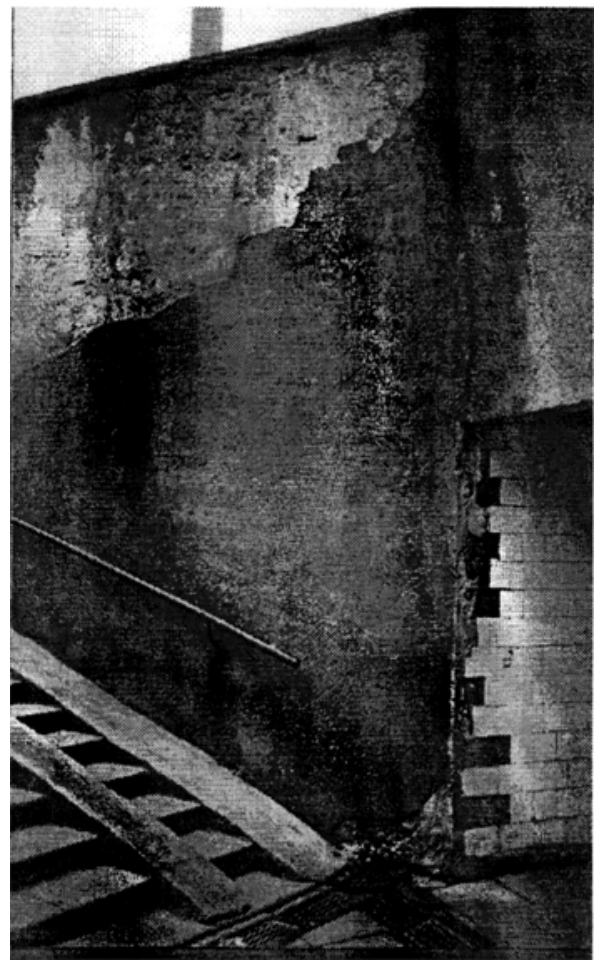

Fig 7. Destruction by exfoliation of decorative plaster and glass tiles from designs of underground passage in the development of Lazdynai after 13 years of service

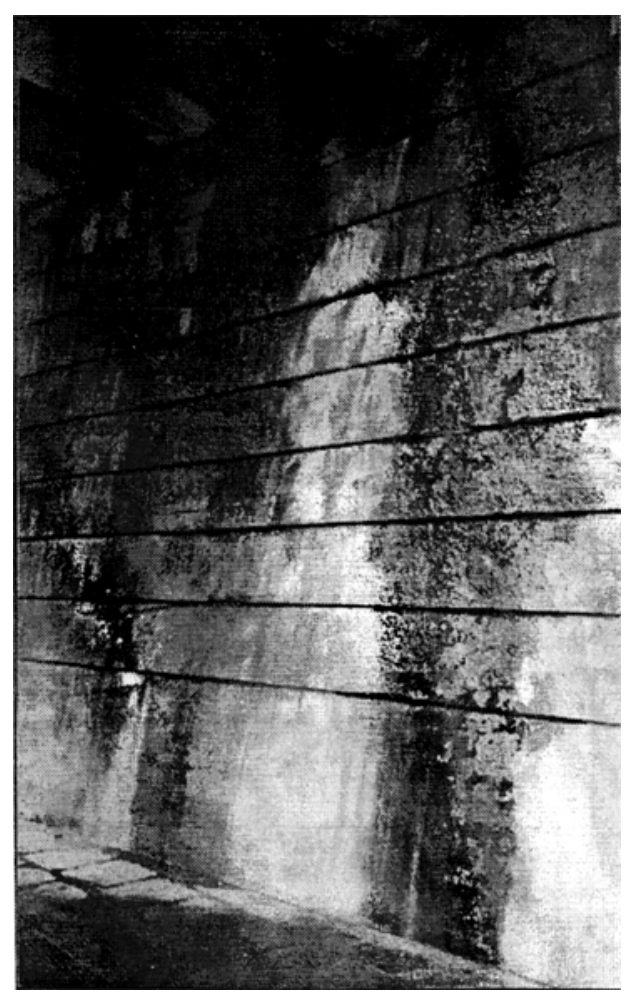

Fig 8. Destruction by exfoliation of monolithic support of concrete viaduct of Valakampiai after 22 years of service under natural conditions
In the second test series with volumetric freezing up to 200 there were carried out and with unilateral freezing - up to 100 cycles of alternate freezingthawing. The results of the tests are given in Fig 9-16. It is evident from the initial data (Fig 9, 10 and Fig 13, 14), that series of sample cubes differ slightly in density and initial saturation. The samples of the first series have a narrower range of density and wider initial saturation (because of open pores) than of the second series. The results of a statistical processing of these characteristic quantities show the sufficient identity of the examined samples. After performance of the tests on frost resistance by different ways of freezing the picture changes. For the first series of concrete samples and for the parameter of final saturation the essential decrease in correlation and substantial growth of disorder of the data is seen. It testifies to a quantitative distinction in proceeding processes of migration and phase transitions of water in porous space, and destruction of concrete while doing tests on frost resistance in different ways. Such conclusion is also confirmed by comparison of residual durability of compression after tests. This parameter correlates well with the previous ones. The second series of samples after tests show the same (Fig 15, 16). The same character of all regression equations remains here. These results completely agree with the known ones for facade ceramic products.

\section{Peculiarities of new standard methods}

As a result of the carried out complex research we have developed two new standards with certain features. Now it is expedient to describe them in short.

The first of the developed standard techniques is intended for testing operational frost resistance of various fragments of natural composites or renovation products if their facing is made of any materials except for one case, when facing layer is made only of polymeric covering. The main criterion of frost resistance of products or materials, irrespective of their planned category, is the possible destruction of the face surface up to $3 \%$ of a tested surface. For a batch the tested surface of samples should not be less than $0.25 \mathrm{~m}^{2}$. Besides, the additional parameter is provided 


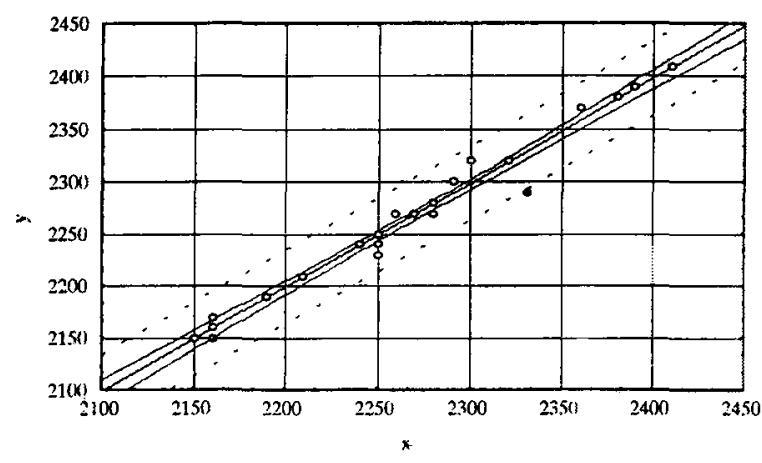

Fig 9. Relationship between density $\left(\mathrm{y}, \mathrm{kg} / \mathrm{m}^{3}\right)$ of concrete samples for volumetric freezing and density $\left(\mathrm{x}, \mathrm{kg} / \mathrm{m}^{3}\right)$ of identical samples for unilateral freezing (the first series of comparative tests). Regression equation: $y=3.2351+$ +0.99770 x. Correlation: 0.9886335 . Std. Err. of Est.: 11.79400

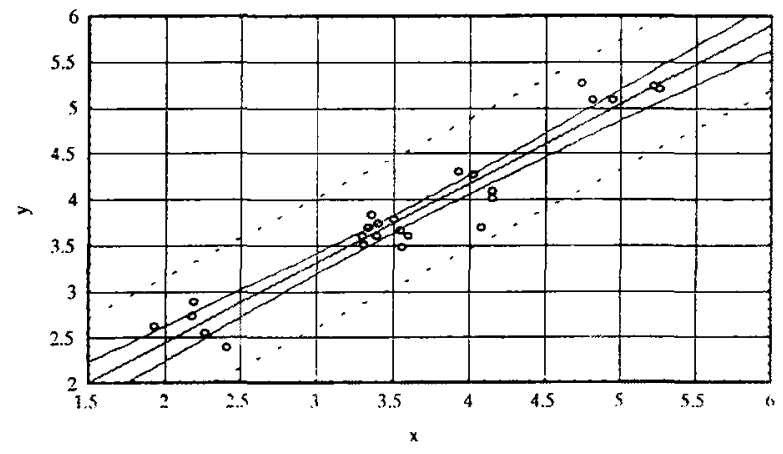

Fig 10. Relationship between initial saturation (y, \%) of concrete samples for volumetric freezing and initial saturation $(x, \%)$ of identical samples for unilateral freezing (the first series of comparative tests). Regression equation: $y=$ $0.70553+0.86540$ x. Correlation: 0.9623988 . Std. Err. of Est.: 0.23583

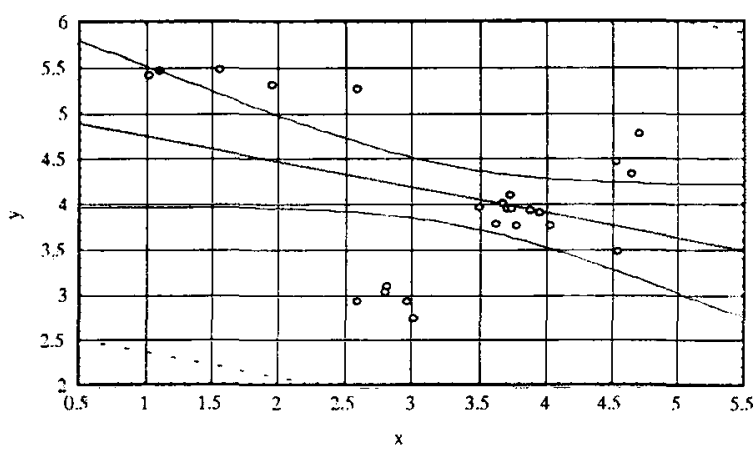

Fig 11. Relationship between final saturation $(y, \%)$ of concrete samples for volumetric freezing and final saturation $(x, \%)$ of identical samples for unilateral freezing (the first series of comparative tests). Regression equation: $y=$ $5.0282-0.2805$ x. Correlation: - 0.358656. Std. Err. of Est.: 0.7941486

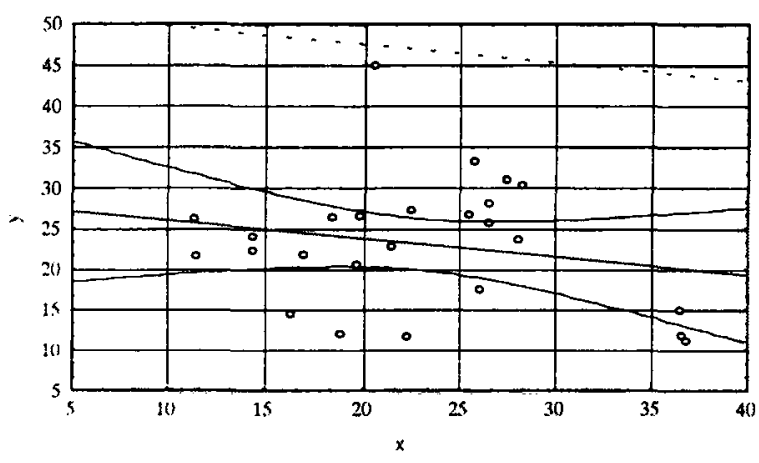

Fig 12. Relationship between compressive strength ( $y$, $\mathrm{MPa}$ ) of concrete samples for volumetric freezing and compressive strength ( $\mathrm{x}, \mathrm{MPa}$ ) of identical samples for unilateral freezing (the first series of comparative tests). Regression equation: $y=28.253-0.2240 \mathrm{x}$. Correlation: 0.203266. Std. Err. of Est.: 7.917654

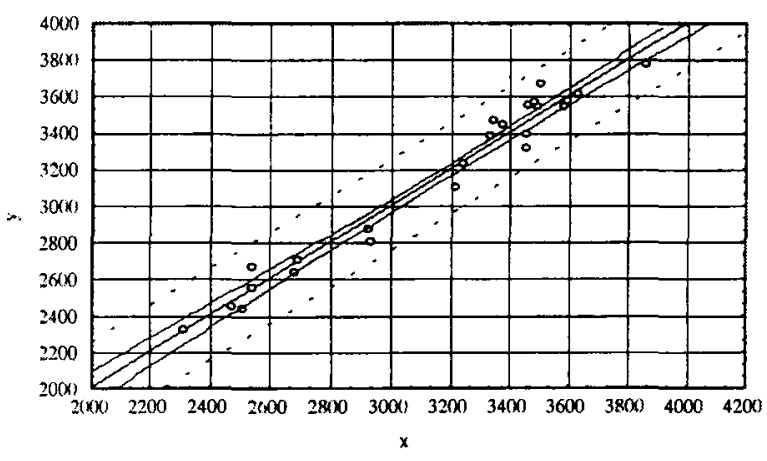

Fig 13. Relationship between density $\left(\mathrm{y}, \mathrm{kg} / \mathrm{m}^{3}\right)$ of concrete samples for volumetric freezing and density $\left(\mathrm{x}, \mathrm{kg} / \mathrm{m}^{3}\right)$ of identical samples for unilateral freezing (the second series of comparative tests). Regression equation:y $=10.698+$ 0.99814 x. Correlation: 0.9849783 . Std. Err. of Est.: 83.25082

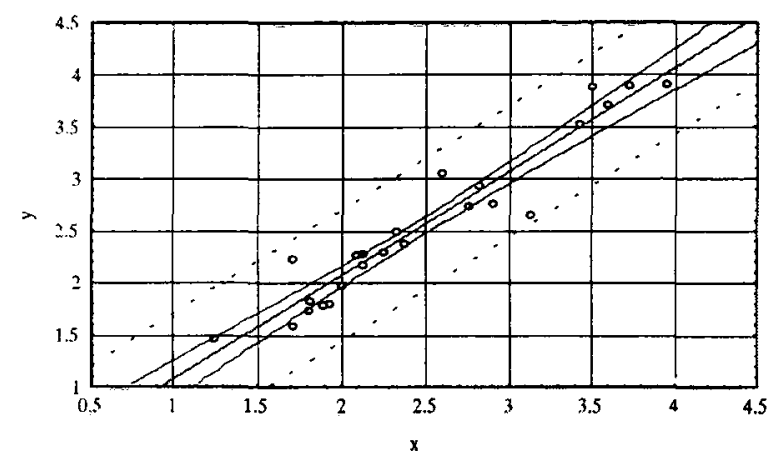

Fig 14. Relationship between initial saturation $(y, \%)$ of concrete samples for volumetric freezing and initial saturation $(x, \%)$ of identical samples for unilateral freezing (the second series of comparative tests). Regression equation: $y$ $=0.079360 .2104677+0.99571$ x. Correlation:0.9629189. Std. Err. Of Est.: 0.2104677 


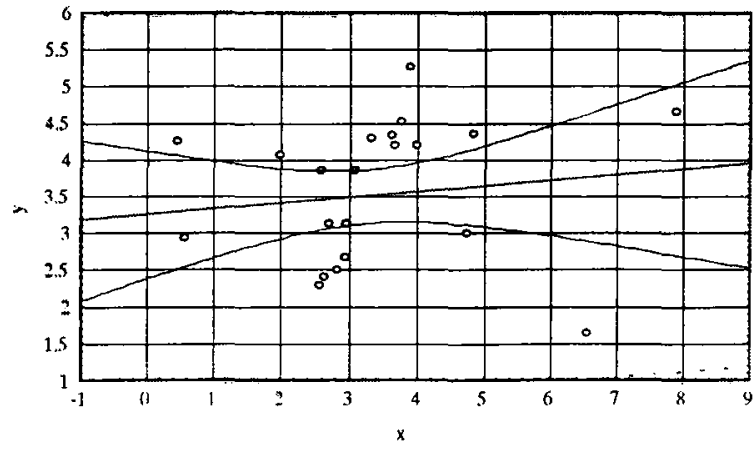

Fig 15. Relationship between final saturation $(y, \%)$ of concrete samples for volumetric freezing and final saturation $(x$, $\%$ ) of identical samples for unilateral freezing (the second series of comparative tests). Regression equation: $\mathrm{y}=$ $3.2528+0.07742$ x. Correlation: 0.1333961 . Std. Err. of Est.: 0.9197421

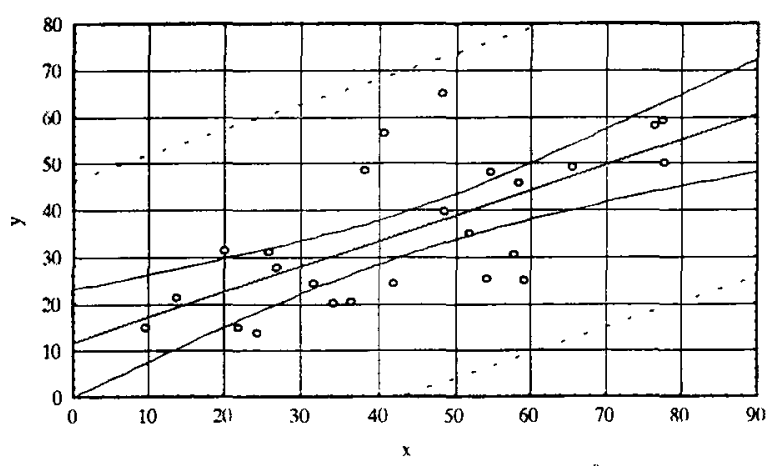

Fig 16. Relationship between compressive strength (y, MPa) of concrete samples for volumetric freezing and compressive strength $(x, M P a)$ of identical samples for unilateral freezing (the second series of comparative tests). Regression equation: $y=11.588+0.54207 \mathrm{x}$. Correlation: 0.6846461. Std. Err. of Est.: 11.58108

as the decrease of initial mass when destruction occurs to the unit of destroyed testified surfaces. It is not predetermined by the standard and depends on the requirements of the customer. Interrelation between 3 conditions of service and appropriate grade of frost resistance (FRE $15 ; 75 ; 125$ ) is forecast in this standard (LST 1413.12:1998; Mortar. Test methods. Determination of frost resistance of plaster and other decoration on one side freezing). The conditions of service are divided into F I, II, III categories. With the increase of a category, operational and climatic conditions of enclosure walls become more difficult.

The similar gradation of concrete durability, especially when the products of them are applied in structures, is stipulated in other standard (LST 1428.19: 1998; Concrete. Test methods. Determina- tion of frost resistance to one-side freezing). It is closely connected with the conditions of service. Thus the basic criteria are accepted: possible decrease in compression strength of samples after appropriate tests, but not more than $15 \%$ and with average possible reduction of a batch of products not more than $0.5 \%$. The additional criterion determines a parameter of water capacity.

The research technique concerning operation or conditions differs slightly. The samples in fragments of structures are tested in freezing-drizzling arrangement (Fig 17).

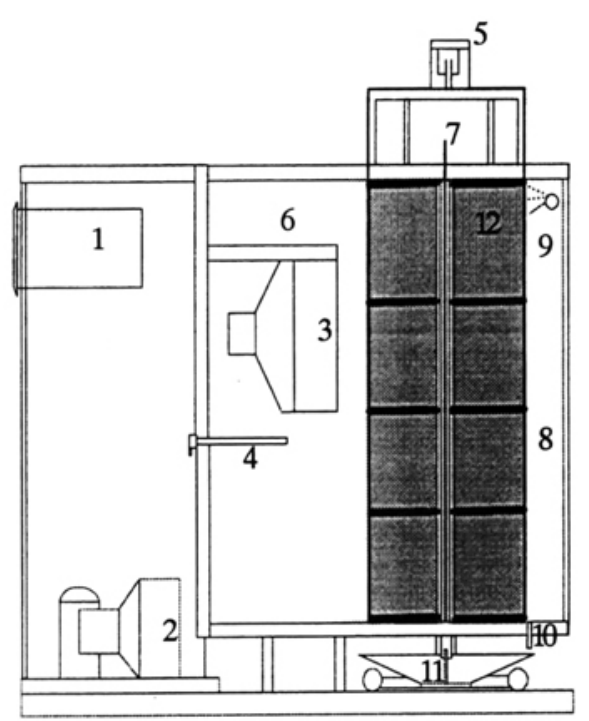

Fig 17. The scheme of freezing-drizzling arrangement: 1 panel; 2 - compressor; 3 - evaporator with a fan; 4 - resistance thermometer; 5 - moving skeleton; 6 - freezing chamber; 7 - rotary section for samples with metal partition; 8 thawing-drizzling section; 9 - sprinkler, 10 - outlet tube, 11 collector of water; 12 - specimens in rotary section

It is necessary to emphasize that these techniques take into account the influence on operational frost resistance by various solutions (salts in water) with reference to definite material categories if such conditions for materials in structures are supposed. It is important that these standards do not have analogues and meet the conditions of protection service in Lithuania.

\section{Conclusions}

1. The analysis of the scientific literature inspection, investigation of maintained structures and the results of the tests show that in winter various facing 
of enclosure walls and structures of concrete basically are destructed from surface to depth (in the same way as the destruction of structures of ceramic products or sand-lime bricks).

2. With the purpose of estimation of durability on operational frost resistance of materials and structures more objectively, their grade of frost resistance should be determined by new standards using techniques of unilateral freezing simulating extreme natural climatic influence.

3. The durability of operational frost resistance of structures in many aspects depends on external (climatic) conditions of their service. These conditions predetermine their category gradation too. However, for the first time (on the example of a climate of Lithuania) the authentic interrelation between categories and grades of operational frost resistance for structural materials and products that ensures sufficient (50-70 years) structures durability is determined.

Responsibility for the quality of structures concerning their durability since now will mostly depend on designers and architects, and the application of our new standards is their prerogative.

\section{References}

1. Р. Мачюлайтис. Основы прогнозирования эксплуатационной морозостойкости и долговечности изделий стеновой керамики. Вильнюс: ЛУГ, 1993 $39 \mathrm{c}$.

2. В. И. Баркаускас. Влияние влажного климата на долговечность слоя наружных стен: Автореф. дис.... канд. техн. наук. М., 1962. 16 c.

3. V. Stankevičius. Pastatu atitvarų drègmine būsena ir atsparumas šalčiui. Kaunas: Technologija, 1997. 142 p.

4. А.c. 1588130 СССР, МКИ G 01 N 33/38. Способ определения морозостойкости стеновых материалов / Р.В. Мачюлайтис, А.С. Садунас, В.А. Могутов, Ю. Ясин, А. П. Кичайте и Г. П. Станкявичюс. № 4499317 / 23-33; Заяв. 19.09.88; Зарегистрировано в Гос. реестре 22.04.90. 5 c.

5. Н. Дрейнер, Г. Смит. Прикладной регрессивный анализ. М.: Статистика, 1970. 359 с

6. R. Mačiulaitis, J. Žvironaité, D. Žemaitytè. Durability of the exterior decorative laminae of buildings // Modern building materials, structures and techniques: Proceedings of $5^{\text {th }}$ international conference. Vol. 1. Vilnius: Technika, 1997, p. $15-20$.

7. R. Maciulaitis. Frost resistance and long service life of ceramic facade products. Part $5 / /$ Ziegelindustrie International. 1997, No 7, p. 427-433.

8. R. Maciulaitis. Frost resistance and long service life of ceramic facade products. Part 5 // Ziegelindustrie International. 1997 , No 9, p. 597-601.
9. Р. Мачюлайтис. Морозостойкость и долговечность изделий фасадной керамики. Вильнюс: Техника, 1997. $308 \mathrm{c}$.

Iteikta 19980708

ATITVARU APDAILOS IR BETONO EKSPLOATACINIO ATSPARUMO ŠALČIUI NUSTATYMO NAU. JU STANDARTINIU METODU PAGRINDIMAS

\section{R. Mačiulaitis, D. Žemaityte̊}

S a n tra k k a

Darbe pateikiamas analizinis ir eksperimentinis nauju standartinių metodų, kuriais nustatomas konstrukcinių kompozitų ir betonų atsparumas šalčiui vienpusio šaldymo būdu, pagrindimas. Remiantis ilgamecių tyrimų rezultatais stebèta ir tirta statinių ir atitvarų būkle ir jos kitimas eksploatacijos salygomis, taip pat ir panasių medžiagu bei konstrukciju irimo procesai modeliuojant eksploatavimo salygas laboratorijoje. Bandinių ar gaminiu atsparumas šalčiui buvo tiriamas klasikiniu tưrinio šaldymo ir mūsu pasiūlytu vienpusio šaldymo būdu specialiu režimu. Tyrimų rezultatai buvo apdorojami matematikos statistiniais metodais. Nustatyta, kad eksploatacinio atsparumo salčiui markę lemia ir konkreti bazinè metodika, ir gaminių kokybé ivvairių savybių požiūriu ir kad apdailos medžiagos irsta panašiai kaip fasadinè keramika. Manyta, kad mūsų gauti rezultatai netinka betonui. Abejonèms išsklaidyti buvo atliktos dvi serijos tyrimų su ivvairių rūsių betono bandiniais. Nustatyta, jog ir müsų sukurtu vienpusio šaldymo, ir klasikiniu tūrinio šaldymo būdu gauti rezultatai pasižymi didele sklaida. Tai pagrindžia būtinumą mūsų metodą taikyti minètoms medžiagoms ir gaminiams. lki šiol Lietuvoje galiojančiose statybos normose ir taisyklèse sienų konstrukcinių medžiagų ir gaminių ilgalaikiškumo ir atsparumo šalčiui markès saryšis neatitinka tikrovès. Ši problema standartuose sprendžiama atitinkamų medžiagu bei gaminiu eksploatacijos salygu arba ilgalaikiškumo bei eksploatacinio atsparumo šalčiui markių nauju sąryšiu ir klasifikacija.

Romualdas MAČIULAITIS. Doctor Habil, Senior Researcher, Associate Professor. Head of Department of Building Materials. Vilnius Gediminas Technical University (VGTU), Sauletekio al. 11, 2040 Vilnius, Lithuania.

A graduate of Vilnius Universitety (1972). Doctor (technical sciences, 1980). Doctor Habil (technical sciences 1993). Associate Professor (1996). Author of about 110 publications. Research interests: durability, frost resistance and other properties of building materials and products, fire prevention in technological processes.

Džigita ŽEMAITYTÉ. Doctoral student. Department of Building Materials. Vilnius Gediminas Technical University (VGTU), Sauletekio al. 11, 2040 Vilnius, Lithuania.

A graduate of Vilnius Gediminas Technical University. BSc (1995), MSc (1997). Research interests: properties of building materials and products. 